\title{
Pemanfaatan Modal Sosial Warga Lokal Dalam Menghadapi Kesulitan Ekonomi Selama Masa Pandemi Covid-19 di Desa Pangumbahan dan Ujunggenteng Kecamatan Ciracap Kabupaten Sukabumi
}

\author{
Arini Dwi Deswanti \\ Politeknik Kesejahteraan Sosial Bandung, arinidwideswanti@ poltekesos.ac.id \\ Ahmad Yaneri \\ Politeknik Kesejahteraan Sosial Bandung, ahmadyaneri@gmail.com
}

\begin{abstract}
This research describes the use of social capital by local residents to help meet the basic living needs of people experiencing economic difficulties during the Covid-19 pandemic at Pangumbahan Village and Ujunggenteng Village, Ciracap District, Sukabumi, West Java. This research uses descriptive qualitative approach with collecting data techniques by in-depth interview, observation, and literature studies. This study uses purposive sampling to find the informants with some criteria. The result of this study found that during the pandemic, local people have drastic decreased income due to lack of tourist that visit tourist attraction at Pangumbahan and Ujunggenteng Village. It causes local people loss their job related to business tourism, so they need to do another job to fulfill their daily needs such as fishing or farming. One of the ways that local people do to face these economic difficulties during pandemic is building fish sellers online community. The conclusion of this study shows that the use of social capital is very helpful for local people to sell their sea catch, so they still have daily income to fulfill their needs during pandemic.
\end{abstract}

\section{Keywords:}

Social capital; pandemic; covid-19; empowerment; community 


\begin{abstract}
Abstrak
Penelitian ini menggambarkan tentang pemanfaatan modal sosial yang dilakukan warga lokal dalam membantu pemenuhan kebutuhan hidup dasar warga yang mengalami kesulitan ekonomi selama masa pandemi Covid-19 di Desa Pangumbahan dan Desa Ujunggenteng Kecamatan Ciracap Kabupaten Sukabumi. Metode penelitian ini menggunakan pendekatan kualitatif dengan jenis penelitian deskriptif. Teknik pengumpulan data dalam penelitian ini menggunakan wawancara mendalam, observasi, dan studi literatur. Teknik pemilihan informan menggunakan teknik purposive. Hasil dari penelitian menunjukan bahwa selama masa pandemi Covid-19, penghasilan warga lokal yang bergantung pada sektor pariwisata mengalami penurunan secara drastis karena menurunnya jumlah wisatawan yang berkunjung ke tempat wisata di Desa Ujunggenteng dan Pangumbahan. Penurunan penghasilan secara drastis selama masa pandemi membuat warga lokal beralih mencari penghasilan tambahan dengan menangkap ikan/ hasil laut lainnya. Salah satu upaya yang dilakukan warga lokal dalam memasarkan hasil tangkapan laut adalah dengan membentuk komunitas online yang beranggotakan para pengepul dan pedagang pasar. Kesimpulan dari penelitian ini menunjukan bahwa pemanfaatan modal sosial salah satunya dengan membentuk grup pengepul dan pedagang pasar secara online sangat membantu warga lokal dalam memasarkan hasil tangkapan laut warga sehingga mereka masih dapat memiliki penghasilan untuk memenuhi kebutuhan sehari-hari selama terhentinya aktivitas ekonomi dari sektor pariwisata karena pandemi Covid-19.
\end{abstract}

\title{
Kata Kunci:
}

Modal sosial; pandemi; covid-19; pemberdayaan; komunitas

\section{PENDAHULUAN}

Corona Virus Disease-2019 (Covid19) telah menjadi pandemi yang melanda seluruh dunia termasuk Indonesia. Kasus Covid-19 pertama kali di Indonesia tercatat pada Maret 2020 di Jakarta (Nugroho, 2020). Pandemi Covid-19 di Indonesia turut berdampak pada sektor ekonomi Indonesia. Indonesia, resmi mengalami resesi akibat pandemi Covid-19 setelah perekonomian Indonesia pada kuartal ketiga tahun 2020 tercatat minus dibandingkan kuartal ketiga tahun 2019. Resesi tahun 2020 merupakan resesi pertama Indonesia setelah krisis moneter tahun 1998 (BBC News Indonesia, 2020). Berdasarkan kajian dari Kementerian Keuangan, pandemi Covid-19 berimplikasi pada menurunnya konsumsi dan daya beli masyarakat, menurunnya kinerja perusahaan, ancaman pada sektor perbankan, dan menurunnya omzet dari UMKM. Pandemi
Covid-19 menyebabkan banyaknya tenaga kerja yang kehilangan pekerjaan sehingga berpengaruh pada menurunnya daya beli masyarakat terutama bagi masyarakat yang merupakan pekerja informal dan pekerja harian (BBC News Indonesia, 2020; Pakpahan, 2020).

Pandemi Covid-19, turut memberikan dampak buruk bagi masyarakat yang bekerja di sektor pariwisata, perdagangan, serta investasi. Berdasarkan data BPS tahun 2019 diketahui terdapat penurunan kedatangan turis asal China ke Indonesia. Hal tersebut berdampak pada menurunnya omzet dari usaha pada sektor pendukung pariwisata seperti restoran dan hotel (Yamali \& Putri, 2020). Adanya kebijakan larangan pariwisata (travel ban) di berbagai negara akibat Covid-19 turut membuat aktivitas sektor pariwisata lesu. Penerapan kebijakan pembatasan mobilitas manusia dan pembatasan wilayah untuk menghindari penyebaran virus, berimplikasi 
pada berhentinya usaha penerbangan, pariwisata, industri dan kegiatan ekonomi lain sebagai akibat adanya kebijakan lockdown di beberapa negara. Hal tersebut menyebabkan, sektor pariwisata menjadi salah satu sektor yang terdampak langsung oleh pandemi (Kementerian Keuangan, 2021).

Pembatalan besar-besaran kunjungan kedatangan wisatawan ke lokasi pariwisata di Indonesia dikarenakan keengganan masyarakat melakukan perjalanan wisata pada masa pandemi Covid-19 membuat penurunan bisnis pariwisata semakin dalam. Hal tersebut mulai berdampak pada terganggunya lapangan kerja dan usaha mikro dan kecil menengah pada sektor pariwisata. Padahal, pariwisata merupakan sektor padat karya yang menyerap lebih dari 13 juta pekerja. Usaha pada sektor pariwisata yang menyerap tenaga kerja paling besar adalah usaha penyedia makan minum $(48,79 \%)$ dan perdagangan $(36,76 \%)$. Jenis usaha pada sektor pariwisata yang lain yang juga berkontribusi dalam penyerapan tenaga kerja adalah penyediaan akomodasi, kegiatan olahraga, dan kreasi lainnya. Selain itu, terdapat pula jenis usaha lainnya seperti kegiatan hiburan, kesenian, kreativitas, transportasi, dan jasa agen perjalanan wisata (Sugihamretha, 2020).

Sebagai contoh, sektor bisnis pariwisata merupakan sektor bisnis unggulan di Bali. Sejak diketahuinya kasus pertama Covid-19 di Indonesia pada bulan maret, tingkat kunjungan wisatawan ke Bali pada bulan maret menurun hampir 50\%. Dikutip dari Balipost (dalam Paramita \& Putra, 2020), kabupaten Badung paling merasakan dampak akibat pandemi Covid-19 yaitu pada April 2020 terdapat 205 perusahaan tutup, dan terdapat 20.272 pekerja yang dirumahkan, serta 235 pekerja di PHK (Paramita \& Putra, 2020).

Begitu pula, dampak pandemi Covid19 juga dirasakan di Desa Pangumbahan dan Desa Ujunggenteng yang menjadi salah satu tujuan wisata di Jawa Barat Sukabumi. Dikeluarkan Surat Keputusan Menteri Kesehatan tentang Pembatasan Sosial Berskala Besar (PSBB) di Provinsi Jawa Barat pada bulan mei 2020, dan Surat Edaran Gubernur Jawa Barat tentang Pelaksanaan Pembatasan Kegiatan Masyarakat dalam Penganganan Covid-19 di Provinsi Jawa Barat pada Januari 2021, yang berisikan tentang himbauan bagi masyarakat di Jawa Barat untuk membatasi kegiatan di fasilitas umum, kegiatan sosial budaya, dan membatasi kapasitas serta jam operasional transportasi umum di wilayah Jawa Barat, secara langsung berdampak pada terganggunya usaha bisnis sektor pariwisata di Jawa Barat, termasuk para pekerja yang mengandalkan penghasilan dari sektor pariwisata di Desa Pangumbahan dan Desa Ujunggenteng, Sukabumi Jawa Barat.

Menguatkan kebijakan PSBB di Jawa Barat, Dinas Pariwisata Kabupaten Sukabumi mengeluarkan Surat Edaran nomor: 556/467/Sekr tentang Penutupan Sementara Tempat Rekreasi dan Penundaan Sementara Kegiatan Tertentu di Lingkungan Tempat Rekreasi Milik Pemerintah Kabupaten Sukabumi (Gilang, 2020a). Camat Ciracap, Deden Sumpena mengatakan bahwa untuk daerah wisata sampai saat ini belum ada edaran dari dinas pariwisata untuk dibuka. Kecamatan Ciracap merupakan salah satu daerah di Kabupaten Sukabumi yang memiliki banyak pilihan Objek Wisata khususnya pantai. Selain Pantai Ujunggenteng dan Pantai Pangumbahan, ada juga Objek Wisata Tanah lot Muara Cikarang. Maka ketika libur lebaran, pengunjung tetap nekat datang meski sudah ada imbauan dari pemerintah Objek Wisata tutup sementara waktu saat Pandemi (dikutip dari Sukabumiupdate.com, Juni 2020) (Gilang, 2020b).

Penelitian ini menggambarkan tentang kesulitan ekonomi warga di Desa Pangumbahan dan Desa Ujunggenteng yang menggantungkan pekerjaan pada sektor 
pariwisata dalam pemenuhan kebutuhan hidup sehari-hari pada masa pandemi Covid-19. Hasil penelitian ini, ditemukan bahwa warga lokal yang sebelum pandemi Covid-19 sangat mengandalkan penghasilan dari bisnis pariwisata di lokasi objek wisata Desa Pangumbahan dan Desa Ujunggenteng sebagai penghasilan utamanya, mengalami penurunan penghasilan yang sangat drastis selama penutupan sejumlah objek wisata pada masa pandemi. Hal tersebut, membuat warga lokal beralih melakukan pekerjaan lain untuk dapat memenuhi kebutuhan hidup sehari-hari seperti menjual hasil tangkapan ikan, dan adapula yang pulang kembali ke tempat tinggal asal untuk bertani.

Teori yang menjadi landasan berpikir dalam penelitian ini menggunakan teori modal sosial. Dari hasil penelitian, diketahui bahwa semakin tinggi modal sosial yang dimiliki komunitas dapat mengurangi kemiskinan dan meningkatkan kesejahteraan komunitas. Dalam konteks pengembangan ekonomi komunitas, diketahui bahwa kurangnya modal sosial yang terbangun dalam komunitas menyebabkan perkembangan ekonomi yang kurang maksimal. Dalam pengembangan ekonomi komunitas, faktor-faktor yang termasuk modal sosial seperti asosiasi komunitas, pengembangan usaha kecil menengah, jejaring sosial, dan aturan-aturan institusi seperti kebijakan atau masukan yang mendukung, merupakan faktor-faktor yang dapat meningkatkan pengembangan ekonomi komunitas (Halstead et al., 2021). Dalam penelitian lain yang mengangkat tentang modal sosial dan pandemi Covid-19, diketahui bahwa modal sosial dalam wujud jejaring sosial pada level makro dapat membantu komunitas dalam mengelola sumberdaya secara lebih baik dalam masa krisis (Wu, 2021).

Dalam literatur lain menyebutkan bahwa modal sosial memiliki peran penting dalam pemberdayaan masyarakat untuk meningkatkan akses pada informasi, partisipasi, penguatan kapasitas organisasi lokal yang bersifat inklusif. Komunitas memiliki kemampuan untuk mengenali potensi yang dimiliki setiap anggotanya. Oleh karena itu, modal sosial yang dimiliki komunitas dapat menguatkan hubungan dan kepercayaan yang terjalin di komunitas tersebut (Fathy, 2019). Kepercayaan yang terbangun dalam komunitas menjadi modal penting bagi komunitas untuk bersama-sama membangun komunitas.

Modal sosial menurut Green (2010) merujuk pada keuntungan finansial dari meningkatnya jumlah dan kerekatan hubungan sosial diantara individu dan pihak-pihak lain di komunitas maupun di luar komunitasnya. Hubungan sosial tersebut menghasilkan modal ekonomi karena membantu masyarakat dalam menemukan pekerjaan (Green \& Goetting, 2010). Modal sosial merujuk pada hubungan antar individu yang seiring berjalannya waktu membentuk jejaring sosial di mana individu individu datang dan saling mengharapkan mendapatkan dukungan dan kepercayaan. Modal sosial dapat mengarah pada 1) meningkatkan potensi, kesehatan fisik, dan kesejahteraaan secara sosial-emosional dalam setiap diri individu; 2) meningkatkan potensi dalam hubungan bermasyarakat dan keanggotaan dalam komunitas di mana individu individu saling berkontribusi dalam meningkatkan keberfungsian masyarakat yang lebih sehat dan efektif (Greenberg et al., 2016). Inti dari modal sosial dalam komunitas adalah terjalinnya jejaring sosial. Jejaring sosial merupakan kelompok orang yang saling terhubung. Jejaring sosial menjadi penting karena mampu memberikan akses ketersediaan dukungan layanan yang dibutuhkan anggota dalam kelompok. Pemberian dukungan tersebut dapat dikatakan sebagai modal dalam modal sosial, yaitu keuntungan yang didapat individu ketika menjalin hubungan dengan individu lain yang memiliki kemampuan/ akses untuk menyediakan dukungan yang 
dibutuhkan. Dua hal penting yang dibutuhkan dalam membangun modal sosial adalah dukungan jejaring sosial dan dukungan sosial. Sebagai contoh, jejaring sosial yang besar tidak cukup membantu komunitas tetapi dibutuhkan jejaring sosial yang dapat memberikan dukungan sosial yang dibutuhkan bagi anggota komunitas yang membutuhkan (Greenberg et al., 2016).

\section{METODE}

Penelitian ini menggunakan pendekatan kualitatif dengan jenis penelitian deskriptif untuk mendapatkan gambaran yang mendalam mengenai kesulitan ekonomi yang dialami warga di Desa Pangumbahan dan Desa Ujunggenteng yang menggantungkan pekerjaan pada sektor pariwisata dalam pemenuhan kebutuhan hidup sehari-hari pada masa pandemi Covid-19. Teknik pengumpulan data dalam penelitian ini menggunakan wawancara mendalam, observasi lapangan, dan studi literatur. Teknik analisa data dalam penelitian ini menggunakan manual koding untuk mengkategorikan data-data yang terkumpul ke dalam sub-sub tema yang serupa. Adapun tahapan proses kategorisasi data yang terkumpul dilakukan melalui open coding, axial coding, dan selective coding.

Teknik pemilihan informan dalam penelitian ini menggunakan teknik purposive. Informan dalam penelitian ini dibedakan menjadi informan kunci dan informan pendukung. Informan kunci dalam penelitian ini adalah informan yang memenuhi kriteria sebagai berikut: 1) informan merupakan warga yang tinggal dan atau menetap di Desa Pangumbahan atau Desa Ujunggenteng; 2) pekerjaan utama informan adalah pekerjaan yang sangat bergantung pada bisnis pariwisata di objek wisata yang ada di Desa Pangumbahan dan Desa Ujunggenteng. Sementara, informan pendukung dalam penelitian ini adalah informan yang mengetahui tentang kebijakan dan informasi terkait penanganan Covid-19 di Desa Pangumbahan dan Desa Ujunggenteng, dan informan yang mengenal dengan baik profil Desa Pangumbahan dan Desa Ujunggenteng.

Didapat tiga informan kunci dan dua informan pendukung dalam penelitian ini. Ketiga informan kunci merupakan warga yang tinggal di Desa Pangumbahan atau Desa Ujunggenteng. Informan 1 memiliki pekerjaan sebagai pemilik rumah makan dan pemilik villa, informan 2 memiliki pekerjaan sebagai pedagang makanan dan minuman, informan 3 memiliki pekerjaan sebagai penyewa dan penjaga villa. Kemudian, didapat 2 informan pendukung dalam penelitian ini yang sangat mengenal dengan baik profil Desa Pangumbahan dan Desa Ujunggenteng yaitu Camat Ciracap dan Ketua Desa Pangumbahan.

\section{HASIL PENELITIAN}

Penelitian dilakukan di Desa Pangumbahan dan Desa Ujunggenteng Kecamatan Ciracap Kabupaten Sukabumi. Kedua desa tersebut dijadikan lokasi penelitian dikarenakan merupakan desa yang memiliki banyak objek wisata dan sebagian besar warga mengandalkan pendapatan dari sektor pariwisata.

Berdasarkan hasil wawancara mendalam dan observasi, diperoleh temuan lapangan menarik yang menggambarkan bagaimana situasi dan kondisi sosial ekonomi warga Desa Pangumbahan dan Ujunggenteng pada masa pandemi Covid-19 sebagai berikut: 1) Kebijakan Gubernur Jawa Barat melakukan PSBB membuat tempat wisata di Jawa Barat di tutup untuk turis sehingga tidak ada turis yang datang ke tempat wisata termasuk yang ada di Desa Pangumbahan dan Ujunggenteng. Hal tersebut menyebabkan menurunnya wisatawan/ turis yang berkunjung ke tempat wisata di Desa Pangumbahan dan Ujunggenteng, sehingga penghasilan warga yang menggantungkan pekerjaan dari bisnis pariwisata menurun drastis. 
2) Sebelum pandemi Covid-19 memasuki Indonesia, pekerjaan warga desa yang menjadi informan dalam penelitian ini sangat bergantung pada sektor pariwisata. Setelah diberlakukannya PSBB dan tidak adanya turis dari luar Sukabumi yang mengunjungi objek wisata di Desa Pangumbahan dan Ujunggenteng membuat informan tidak mendapatkan penghasilan sehingga kesulitan untuk memenuhi kebutuhan hidup sehari-hari. Oleh karena itu, informan beralih pekerjaan lain seperti menangkap ikan di laut, atau kembali ke kampung asal dan bertani.

Berdasarkan data yang diperoleh dari informan kunci, diketahui bahwa mereka mengalami penurunan pendapatan yang signifikan pada masa pandemi Covid-19. Gubernur Jawa Barat memberlakukan PSBB mulai bulan April hingga pemberlakuan adaptasi kebiasaan baru pada bulan Agustus 2020. Dengan kata lain, sejak April hingga Agustus 2020 (selama 4 bulan) seluruh tempat wisata ditutup termasuk tempat wisata yang berada di Desa Pangumbahan dan Ujunggenteng. Hal tersebut membuat tidak adanya wisatawan dari luar kota yang berkunjung ke kedua desa tersebut sehingga penghasilan ketiga informan kunci yang berasal dari turis dengan menyewakan villa atau menjual dagangan kepada turis menjadi turun bahkan nol. Ketiga informan mengatakan bahwa sebelum pandemi, dalam sehari mereka bisa mendapatkan penghasilan sampai 1 juta rupiah dengan berjualan di pinggir pantai atau dengan menyewakan villa. Selama pandemi, dalam seminggu penghasilan yang mereka dapatkan antara 100.000-200.000 bahkan ada hari dimana mereka sama sekali tidak mendapatkan penghasilan.

3) Ketika Covid-19 memasuki wilayah Sukabumi dan diberlakukan PSBB, bertepatan dengan masa panen padi di Kecamatan Ciracap yaitu pada bulan Juli dan Agustus. Informan A yang sebelum masa pandemi bekerja menjajakan dagangan makanan dan minuman di objek wisata Pantai Ujunggenteng, selama PSBB pada masa pandemi Covid-19 beralih pekerjaan sebagai petani. Latar belakang pendidikan informan A adalah lulusan SD. Selama PSBB pada masa pandemi Covid-19, informan A kembali ke kampung asal di mana informan A masih memiliki kebun dan sawah untuk ditanami berbagai macam umbi-umbian dan padi sehingga selama PSBB, yang bertepatan dengan musim panen padi, informan masih bisa memenuhi kebutuhan sehari-hari dengan menjual hasil padi dan hasil kebun lainnya. Selama PSBB masa pandemi Covid-19, informan A mengandalkan hasil kebun untuk kebutuhan makan sehari-hari. Jika hasil kebun berlebih, informan A akan menjual hasilnya dan menggunakan uangnya untuk memenuhi kebutuhan yang lain.

4) Latar belakang pendidikan informan $B$ adalah lulusan SMA. Informan B beralih pekerjaan dari yang biasanya menyewakan villa menjadi nelayan dan harus menangkap ikan dari laut terlihat tidak memiliki keterampilan yang mumpuni dalam menangkap ikan sehingga hasil tangkapannya hanya cukup untuk memenuhi kebutuhan hidup sehari-hari dan tidak mampu menangkap ikan dalam jumlah besar. Informan menangkap ikan dengan cara memancing di tepi laut dan tidak menggunakan perahu untuk memancing di tengah laut. Selama PSBB masa pandemi Covid-19, informan B mengandalkan upah harian dari menangkap dan menjual hasil laut.

5) Informan $C$ yang sebelum pandemi bekerja sebagai pemilik rumah makan laut dan pemilik villa, selama masa pandemi beralih pekerjaan menjual hasil laut dari tangkapan warga yang memancing laut dari tepian pantai. Informan C tidak bisa memancing laut di perahu karena sering mengalami mabuk laut. Berdasarkan informasi dari informan $\mathrm{C}$ diketahui pula hampir sebagian besar warga yang tinggal di Desa Pangumbahan dan Desa Ujunggenteng tidak bisa berenang dan cenderung menangkap ikan dari tepi pantai karena takut tenggelam 
jika menangkap ikan menggunakan perahu. Informan $\mathrm{C}$ memiliki latar belakang pendidikan S2 dan memiliki pekerjaan tetap sebagai guru Sekolah Dasar. Informan tersebut membeli hasil tangkapan laut warga yang kehilangan pekerjaan karena masa PSBB. Walaupun hasil tangkapan warga tidak sebanyak dengan hasil tangkapan nelayan yang menggunakan perahu, tetapi setiap hari selalu ada warga yang menawarkan hasil tangkapan ikannya kepada informan. Dengan kata lain, informan tersebut menjadi pengepul yang membeli hasil tangkapan laut warga kemudian menjualkan tangkapan laut tersebut di Pasar Lelang Ikan setempat.

Total terdapat 10 warga yang rutin menjualkan hasil tangkapan lautnya kepada informan C. Sepuluh warga tersebut merupakan warga yang kehilangan pekerjaan selama PSBB masa pandemi Covid-19, dan kesepuluh warga tersebut memancing ikan dari tepi pantai dan tidak menggunakan perahu. Informan $\mathrm{C}$ merupakan informan yang cukup memiliki akses dan pengetahuan. Salah satu upaya yang dilakukan informan $\mathrm{C}$ untuk meningkatkan hasil tangkapan laut dari warga setempat yaitu mengajarkan penggunaan aplikasi fishing point pada warga setempat. Aplikasi tersebut membantu warga mengetahui kekuatan arus/ ombak laut dan keberadaan titik kumpul ikan. Dengan menggunakan aplikasi tersebut, warga dapat mengetahui titik titik dimana terdapat banyak ikan sedang berkumpul sehingga warga dapat menangkap banyak ikan.

Selain itu, informan $\mathrm{C}$ juga bergabung dengan komunitas online pedagang di pasar pelelangan ikan untuk memudahkan informan C menjual tangkapan laut yang dimilikinya. Informan $\mathrm{C}$ tetap merasakan adanya penurunan penghasilan tetapi penghasilan yang diterima informan $\mathrm{C}$ dibandingkan ke 2 informan lain, masih lebih besar informan $\mathrm{C}$ karena informan $\mathrm{C}$ masih memiliki penghasilan tetap dari pekerjaannya sebagai guru Sekolah Dasar, selain itu, informan C mendapatkan penghasilan dari menjual tangakapan hasil laut warga sekitar.

\section{PEMBAHASAN}

Berdasarkan hasil temuan lapangan, diketahui bahwa dari ketiga informan dapat mengatasi kesulitan ekonomi selama PSBB masa pandemi Covid-19 dengan beralih pekerjaan lain. Namun, penghasilan yang didapat dari pekerjaan yang dilakukan oleh ketiga informan hanya cukup untuk memenuhi kebutuhan hidup sehari-hari dan jelas berbeda jauh dengan penghasilan yang biasa diterima oleh informan sebelum pandemi Covid-19. Namun, dari hasil temuan lapangan dapat terlihat bahwa kemampuan informan $\mathrm{C}$ dalam mengatasi kesulitan ekonomi selama PSBB pada masa pandemi Covid-19 lebih baik dibanding dengan informan A dan informan B. Selain karena informan $\mathrm{C}$ memiliki penghasilan tetap, ditambah informan $\mathrm{C}$ mampu memanfaatkan modal sosial sebagai tambahan penghasilan yaitu bekerja sebagai pengepul tangkapan hasil laut dari warga sekitar dan menjualkannya ke pasar.

Modal sosial yang dilakukan informan C selama PSBB adalah dengan memperkuat jejaring dan dukungan sosial komunitas di wilayah tempat tinggalnya. Informan $\mathrm{C}$ mampu mengumpulkan dan menghubungkan warga setempat yang kehilangan pekerjaan selama PSBB pada masa pandemi untuk menjual hasil tangkapan laut kepada dirinya. Tidak hanya itu, informan $\mathrm{C}$ yang merupakan warga asli di wilayah setempat, sangat mengetahui kelemahan warga di mana hampir sebagian besar warga tidak berani menangkap ikan menggunakan perahu di tengah laut karena tidak bisa berenang dan takut tenggelam. Oleh karena itu, warga hanya bisa menjual hasil tangkapan laut dalam jumlah kecil ke informan $\mathrm{C}$ yang merupakan hasil tangkapan laut warga dari tepian pantai saja. Untuk menambah dan 
menyiasati hasil tangkapan laut warga tersebut, informan $\mathrm{C}$ mengenalkan dan mengajarkan cara penggunaan aplikasi fishing point sehingga warga dapat mengetahui titik titik tempat di mana banyak ikan berkumpul. Peran dari informan $\mathrm{C}$ dalam memberikan dukungan sosial bagi lingkungan tempat tinggalnya tergambarkan pada ilustrasi 1 di bawah ini.

Selain itu, informan $\mathrm{C}$ juga membangun jejaring sosial dengan para pedagang pasar ikan lelang setempat. Jejaring sosial tersebut diwujudkan dalam komunitas kelompok online melalui whatsapp group. Dalam komunitas kelompok online tersebut, informan $\mathrm{C}$ menawarkan hasil tangkapan laut kepada para pedagang lain yang selanjutnya hasil tangkapan lautnya langsung dipasarkan kepada pembeli.

Ilustrasi 1: Informan C sebagai pemberi dukungan sosial di lingkungan tempat tinggalnya

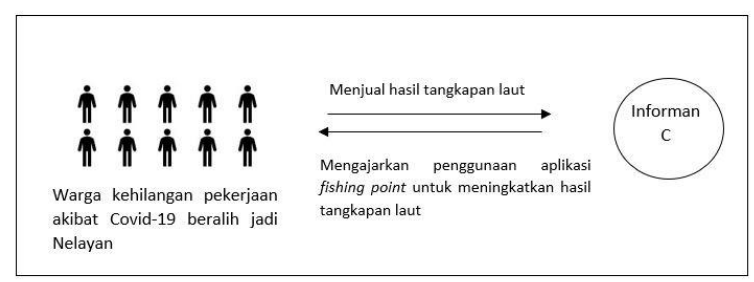

Komunitas Kelompok online tersebut tidak hanya digunakan informan $\mathrm{C}$ untuk menjualkan hasil tangkapan ikan kepada pedagang lain tetapi juga sebagai media bagi informan $\mathrm{C}$ jika ada permintaan ikan khusus dari pedagang di komunitas tersebut maka informan $\mathrm{C}$ akan mencarikan ikan tersebut. Peran dari informan $\mathrm{C}$ dalam membangun jejaring sosial yaitu membentuk komunitas pedagang online sebagai upaya informan untuk memasarkan hasil tangkapan laut secara lebih luas tergambarkan pada ilustrasi 2 di bawah ini.
Ilustrasi 2: Informan C membangun jejaring sosial dalam bentuk komunitas pedagang online pada masa pandemi Covid-19

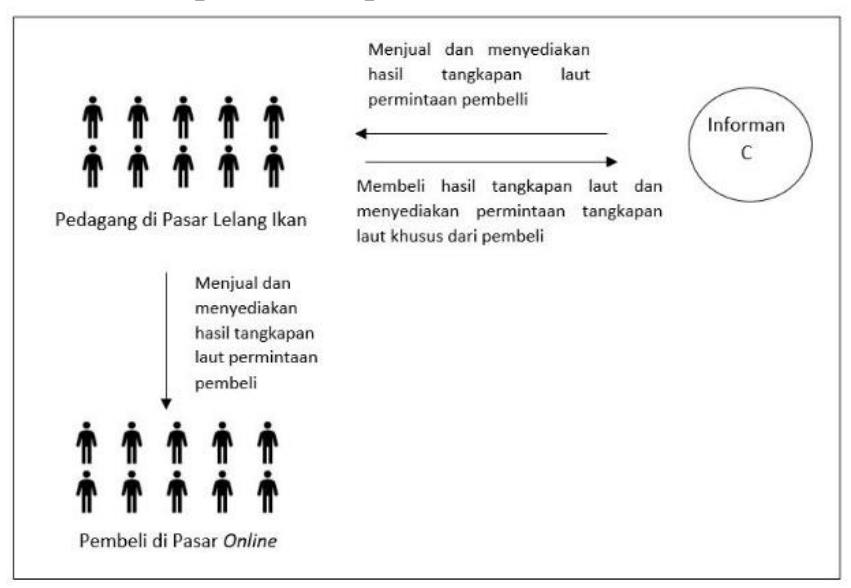

Berdasarkan upaya yang dilakukan oleh informan $\mathrm{C}$, tergambarkan dengan jelas bagaimana informan $\mathrm{C}$ membangun modal sosial di lingkungannya sebagai upaya adaptasi yang dilakukan dalam menghadapi kesulitan ekonomi akibat diberlakukannya PSBB pada masa pandemi Covid-19. Terlihat bahwa pengembangan modal sosial pada ilustrasi 1 yang dilakukan oleh informan $\mathrm{C}$ yaitu meningkatkan akses informasi, partisipasi dari warga lokal melalui penggunaan aplikasi fishing point untuk meningkatkan hasil tangkapan laut warga lokal. Upaya informan C mengajarkan penggunaan aplikasi modern tersebut adalah bentuk pemberian penguatan kapasitas bagi warga lokal. Tentunya, hal tersebut menguntungkan bagi kedua belah pihak. Warga lokal bisa mendapatkan lebih banyak penghasilan dengan menjual tangkapan hasil laut yang lebih banyak, dan informan $\mathrm{C}$ bisa mendapatkan untung yang lebih besar dengan menjual tangkapan laut yang lebih banyak kepada pedagang di pasar lelang ikan.

Selanjutnya, pada ilustrasi 2, tergambarkan bahwa pengembangan jejaring sosial yang dilakukan oleh informan C membuka akses kesempatan yang lebih luas bagi informan $\mathrm{C}$ dalam memasarkan hasil tangkapan laut yang ditampung oleh informan C. Dengan dibentuknya komunitas online 
pedagang pasar lelang, membuka kesempatan bagi informan $\mathrm{C}$ dapat menjual hasil tangkapannya tidak hanya sebatas kepada pedagang tetapi juga kepada pembeli langsung melalui bantuan dari pedagang di pasar lelang. Tentunya, aktivitas tersebut dilakukan melalui komunikasi secara online. Aktivitas yang tergambar pada ilustrasi 2 juga menunjukan bahwa semua pihak yang terlibat saling mendapatkan keuntungan. Informan $\mathrm{C}$ mendapatkan untung lebih besar karena bisa memasarkan hasil tangkapan laut kepada banyak pedagang di komunitas online, Pedagang di komunitas online dapat membeli langsung hasil tangkapan ikan dan bahkan bisa memenuhi permintaan dari pembeli langsung bagi pembeli yang menginginkan hasil tangkapan laut tertentu kepada informan C. Begitu pula dengan pembeli online, mendapatkan keuntungan dengan tersedianya produk yang diinginkan.

\section{KESIMPULAN}

Pandemi Covid-19 yang melanda Indonesia turut berdampak pada penghasilan warga pesisir di Desa Pangumbahan dan Ujunggenteng. Bagi warga pesisir yang sangat mengandalkan penghasilan dari sektor pariwisata, pandemi Covid-19 yang mengakibatkan ditutupnya seluruh tempat pariwisata di sekitar Desa Pangumbahan dan Ujunggenteng membuat penghasilan warga dari sektor pariwisata menurun drastis bahkan sama sekali tidak ada pendapatan. Namun, dengan memanfaatkan modal sosial, warga lokal tetap dapat melewati kondisi perekonomian yang sulit selama masa pandemi Covid-19. Walaupun penghasilan yang didapat selama masa pandemi tidak sebanyak penghasilan yang didapat sebelum masa pandemi, setidaknya warga masih dapat memenuhi kebutuhan hidup sehari-hari.

Pemanfaatan modal sosial sangat berperan dalam membantu warga lokal bertahan dalam krisis ekonomi dan beradaptasi dengan kondisi yang baru. Sebagai adaptasi kebiasaan baru di mana gerak sosial sangat dibatasi dan hanya bisa dilakukan secara online, membangun jejaring sosial dan membentuk komunitas online terbukti dapat membantu warga di Desa Pangumbahan dan Desa Ujunggenteng dalam memasarkan hasil tangkapan laut mereka.

Kedepan, diperlukan program pemberdayaan atau pembangunan komunitas yang bisa memberikan pengetahuan terkait pengelolaan modal/ aset warga pesisir sehingga warga pesisir dapat memaksimalkan modal yang mereka miliki yang dapat memberikan penghasilan yang lebih menguntungkan bagi mereka dibanding saat ini. Seperti memaksimalkan modal teknologi, modal lingkungan, dan modal manusia yang masih bisa dikembangkan secara lebih optimal.

Sebagai gambaran, 2 dari 3 informan dalam penelitian ini memiliki latar belakang pendidikan yang rendah sehingga tidak memiliki cukup banyak pengetahuan dalam penggunaan teknologi modern terkini yang dapat membantu mereka dalam meningkatkan penghasilan. Selain itu, modal lingkungan di Desa Pangumbahan dan Desa Ujunggenteng juga masih dapat dioptimalkan untuk meningkatkan kesejahteraan hidup warga lokal. Kondisi geografis kedua desa tersebut dapat dikategorikan sebagai desa pesisir dan desa pinggiran hutan dengan topografi wilayah datar berbukit yang memiliki potensi tidak hanya dibidang kekayaan laut tetapi juga pertanian dan perkebunan. Kondisi lingkungan di kedua desa tersebut sangat kaya akan sumber daya alam baik dari hasil pertanian maupun hasil laut.

Selain itu, modal manusia juga bisa menjadi sasaran utama dalam pengembangan komunitas di Desa Pangumbahan dan Desa Ujunggenteng. Seperti diketahui, sebagian besar warga lokal tergambarkan tidak bisa berenang dan takut tenggelam, hal tersebut menyebabkan warga lokal lebih memilih 
memancing ikan dari tepi pantai dibanding memancing menggunakan perahu di tengah laut. Jika dari tepi pantai warga bisa mendapatkan cukup ikan, terdapat kemungkinan besar bahwa warga bisa mendapatkan banyak ikan jika memancing di tengah laut menggunakan perahu. Usulan bagi penelitian aksi ataupun pengabdian yang dapat dilakukan di Desa Pangumbahan dan Desa Ujunggenteng salahsatunya dengan mengajarkan keterampilan berenang, memancing, dan mengendarai perahu sehingga warga lokal dapat mengolah lebih banyak hasil laut dibanding yang sekarang dilakukan.

\section{DAFTAR PUSTAKA}

BBC News Indonesia. (2020, November 5). Resesi ekonomi Indonesia: Pemerintah disarankan fokus "menangani pandemi” demi perbaikan ekonomi. BBC News Indonesia. https://www.bbc.com/indonesia/indone sia-53152994

Fathy, R. (2019). Modal sosial: Konsep, inklusivitas dan pemberdayaan masyarakat. Jurnal Pemikiran Sosiologi, 6(1), 1-17.

Gilang, R. (2020a, March 24). Objek Wisata di Ciracap Sukabumi Ditutup Sementara. https://sukabumiupdate.com/detail/vak ansi/wisata/66598-Objek-Wisata-diCiracap-Sukabumi-Ditutup-Sementara

Gilang, R. (2020b, June 2). Kapan Wisata di Ujunggenteng Sukabumi Kembali Buka? Ini Kata Camat Ciracap. https://sukabumiupdate.com/detail/suk abumi/peristiwa/70416-Kapan-Wisatadi-Ujung-Genteng-Sukabumi-

Kembali-Buka-Ini-Kata-CamatCiracap

Green, G. P., \& Goetting, A. (2010). Mobilizing communities. Temple University Press.
Greenberg, A. G., Gullotta, T. P., \& Bloom, M. (2016). Social Capital and Community Well-Being: The Serve Here Initiative. Springer International Publishing. https://books.google.co.id/books? $i d=\_j$ vADAAAQBAJ

Halstead, J. M., Deller, S. C., \& Leyden, K. M. (2021). Social capital and community development: Where do we go from here? Community Development, 1-17. https://doi.org/10.1080/15575330.2021 .1943696

Kementerian Keuangan. (2021). Merekam Pandemi Covid-19 dan Memahami Kerja Keras Pengawal APBN. Kementerian Keuangan. https://www.kemenkeu.go.id/media/18 295/buku-merekam-pandemi-covid19-dan-memahami-kerja-keraspengawal-apbn.pdf

Nugroho, R. S. (2020, April 11). Mengetahui Sejumlah Klaster Awal Penyebaran Virus Corona di Indonesia. Kompas.com. https://www.kompas.com/tren/read/20 20/04/11/193000565/mengetahuisejumlah-klaster-awal-penyebaranvirus-corona-di-indonesia?page $=$ all

Pakpahan, A. K. (2020). Covid-19 dan implikasi bagi usaha mikro, kecil, dan 
menengah. Jurnal Ilmiah Hubungan Internasional, 59-64.

Paramita, I. B. G., \& Putra, I. G. G. P. A. (2020). New Normal Bagi Pariwisata Bali Di Masa Pandemi Covid 19. Pariwisata Budaya: Jurnal Ilmiah Agama Dan Budaya, 5(2), 57-65.

Sugihamretha, I. D. G. (2020). Respon Kebijakan: Mitigasi Dampak Wabah Covid-19 Pada Sektor Pariwisata. Jurnal Perencanaan Pembangunan: The Indonesian Journal of Development Planning, 4(2), 191-206.
Wu, C. (2021). Social capital and COVID-19: A multidimensional and multilevel approach. Chinese Sociological Review, 53(1), 27-54. https://doi.org/10.1080/21620555.2020 .1814139

Yamali, F. R., \& Putri, R. N. (2020). Dampak Covid-19 Terhadap Ekonomi Indonesia. Ekonomis: Journal of Economics and Business, 4(2), 384388. 